九州大学学術情報リポジトリ

Kyushu University Institutional Repository

\title{
Charcoals Evaluation Regarding the Effect of Preservative-Treated Woods Leached Metal Loss on Water-Based Environment
}

Lin, Han Chien

Laboratory of Environment Functional Materials, Department of Wood Based Materials and Design, College of Agriculture, National Chiayi University

Li, Shiou-Ting

Graduate Institute of Forestry and Natural Resources, College of Agriculture : Master

Shiah, Tsang-Chyi

Department of Wood Based Materials and Design, College of Agriculture, National Chiayi University

Duh, Ming-Hong

Department of Wood Based Materials and Design, College of Agriculture, National Chiayi University

他

https://doi.org/10.5109/1686489

出版情報：九州大学大学院農学研究院紀要. 61 (2)，pp.351-359，2016-09-01. Faculty of Agriculture, Kyushu University

バージョン :

権利関係 : 


\title{
Charcoals Evaluation Regarding the Effect of Preservative-Treated Woods Leached Metal Loss on Water-Based Environment
}

\author{
Han Chien LIN ${ }^{1}$, Shiou-Ting $\mathbf{L I}^{2}$, Tsang-Chyi SHIAH ${ }^{3 *}$, \\ Ming-Hong DUH ${ }^{3}$ and Noboru FUJIMOTO
}

\author{
Laboratory of Wood Material Technology, Division of Sustainable Bioresources Science, \\ Department of Agro-environmental Sciences, Faculty of Agriculture, \\ Kyushu University, Fukuoka 812-8581, Japan \\ (Received April 28, 2016 and accepted May 10, 2016)
}

\begin{abstract}
This study used the adsorption of charcoals (bamboo charcoal and Bey-Charng charcoal) to evaluate the effect of the metal components leached from CCA- and ACQ-treated woods on water-based environment, especial for water quality and fish (Oreochromis hybrids) body in a 48-week long period. The retention contents of $\mathrm{CrO}_{3}, \mathrm{As}_{2} \mathrm{O}_{5}$, and $\mathrm{CuO}$ in the CCA-treated wood were $1.15,0.44$, and $0.12 \mathrm{~kg} / \mathrm{cm}^{3}$, respectively, after 48 weeks; the retention content of $\mathrm{CuO}$ in the ACQ-treated wood was $0.13 \mathrm{~kg} / \mathrm{cm}^{3}$. The iodine value of bamboo charcoal and Bey-Charng charcoal was $146.99 \mathrm{mg} / \mathrm{g}$ and $109.85 \mathrm{mg} / \mathrm{g}$, respectively, before testing, and the methylene blue adsorption value was $712.13 \mathrm{mg} / \mathrm{g}$ and $642.36 \mathrm{mg} / \mathrm{g}$, which decreased with time after 48 weeks. According to the water quality analysis results, the electrical conductivity of water with charcoals was higher than that without charcoals at the initial stage, and the $\mathrm{pH}$ value of that with charcoals was kept above 7. After the test, the contents of heavy metals $\mathrm{Cr}, \mathrm{As}$, and $\mathrm{Cu}$ ions in the water without charcoals were $0.038,0.697$, and $0.709 \mathrm{ppm}$; the contents in the water with charcoals were $0.020-0.022,0.472-0.469$, and $0.001-0.139 \mathrm{ppm}$, respectively, the As content was higher than the drinking water standard $(0.01 \mathrm{ppm})$ of the Environmental Protection Administration, Executive Yuan, and the $\mathrm{Cr}$ and $\mathrm{Cu}$ contents were lower than the standard 0.05 and $1.0 \mathrm{ppm}$. Therefore, the adsorption of charcoals has a certain effect of preservativetreated woods leached metal loss on the water quality in water-based environment.
\end{abstract}

Key words: Bamboo Charcoal, Bey-Charng Charcoal, Absorption, CCA-treated Wood, ACQ-treated Wood, Leaching

\section{INTRODUCTION}

In terms of the degradation of wood subject to biological attack, using wood preservatives to treat wood is the simplest and most effective method (Hunt and Garratt, 1975; Findlay, 1985). There are great varieties of wood preservatives; the Chromated Copper Arsenate (CCA) wood preservatives is one of the most famous wood waterborne preservatives in the world at present, and is made of Copper (Cu), Chromium (Cr), and Arsenic (As) salts. The wood treated with CCA has satisfactory results of preventing biological attack by ponds, and in streams and seas; however, it pollutes the environment, such as heavy metals, which hazard the water quality, fishes, planktons, and aquatic plants (Weis et al., 1995; Caquet et al., 1996; Brown and Eaton, 2001).

Theoretically, CCA is long-term and stably stored in wood by the chemical reaction of fixation, but it is likely to be influenced by the $\mathrm{pH}$ value, lignin content and structural formula, and extracts content, and it is easily to leach out different quantities of $\mathrm{Cu}, \mathrm{Cr}$, and $\mathrm{As}$ in the water. Cr VI is reduced to less toxic $\mathrm{Cr}$ III and is a cancerogenous substance. $\mathrm{Cu}$ is a toxic substance when its

${ }^{1}$ Laboratory of Environment Functional Materials, Department of Wood Based Materials and Design, College of Agriculture, National Chiayi University, Chiayi, Taiwan, ROC

Master, Graduate Institute of Forestry and Natural Resources, College of Agriculture, Chiayi, Taiwan, ROC

Department of Wood Based Materials and Design, College of Agriculture, National Chiayi University, Chiayi, Taiwan, ROC

* Corresponding author (E-mail: teshiah@mail.ncyu.edu.tw) quantity is large. As is known as one of the most poisonous carcinogenic substances (Sanders and Windom, 1980; Sanders and Riedel 1987; Weis J. S. and P. Weis, 1992a, 1992b, 1995, 1996; Weis P. and J. S. Weis, 1999). The hazard and pollution of CCA; therefore, have received global attention. CCA was prohibited in Germany, Japan, and Indonesian in 2000, and prohibited in other European countries and the USA in 2004. Taiwan has standards for the use of CCA (CNS 14495 and CNS 3000), but it will be prohibited on $1^{\text {st }}$ January, 2016. The universal substitute Ammoniacal Copper Quats (ACQ) is most used as a wood preservatives, as its composition only keeps $\mathrm{Cu}$, and is free of carcinogenic and heavy metal elements $\mathrm{Cr}$ and As, thus, its safety in operation is higher than CCA. However, as environmental considerations gradually rise, social sensitivity to the effect of chemical substances on the environment grows accordingly. The safer ACQ is supposed to be used in Taiwan's wood preserving industry extensively in the future, but safety issues may still occur, and the leached $\mathrm{Cu}$ from ponds, streams, and seas may have negative effect on water quality, animals, and plants.

At present, the adsorption process is the most direct and effective method for the environmental pollution of water sources and relative industries, and the recovery and disposal of organic contaminants. The common adsorbents include activated aluminum, silica gel, and charcoals. The structure of charcoal has numerous pores and excellent adsorption characteristics (Lin et al., 2003; Hung, 2004). Therefore, the study aimed to evaluate the adsorption ability of charcoals for the metal components leached from CCA or ACQ in an aquarium in the long- 
term, in order to reduce the effect on water-based environment, water quality and fish body, regarding heavy metal absorption. The results diversify the utility value of charcoals, and provide indices for Taiwan's wood preservation and bamboo industries.

\section{MATERIALS AND METHODS}

\section{Test materials}

$C C A$ - and $A C Q$-treated wood

The tangential lumbers of Japanese cedar (Cryptomeria japonica D.Don) were used as test specimens, and the size is $285 \times 75 \times 10 \mathrm{~mm}$. The test specimens were treated with CCA and ACQ. The wood preservatives were Type 3 of chromated copper arsenate (CCA-3) and Type 1 of ammoniacal copper quats (ACQ1). The specimens had a moisture content of less than $15.0 \%$ after being air-dried at ambient temperatures. They were then impregnated with CCA-3 or ACQ-1 according to the procedure "Breant-Bethell" (one of full-cell treatments) of CNS 3000 standard. The preparations of the specimens were referred to (Lin et al., 2006). The above test specimens were provided by Kunnyih Co. Ltd., Yilan, Taiwan.

Charcoals

The bamboo charcoal was made from Moso bamboo (Phyllostachys heterocycla Milf) carbonized at $700^{\circ} \mathrm{C}$. The wood charcoal (Bey-Charng charcoal) was made from Ring-cupped oak (Cyclobalanopsis glauca (Thunb.) Oerst) wood. Bey-Charng charcoal was prepared at $1000^{\circ} \mathrm{C}$ of carbonization temperature. Both were purchased from Yuen Hung Industry Co., Ltd., Taichung, Taiwan

Fish

Taiwan porgy (Oreochromis hybrids), also known as Tilapia, Cichlidae, originated from Africa, were provided by Yihua Fry Unisexual Cultivation Farm, Taiwan.

Source of water sample and fish bowl

Water-based sample was the tap water of National Chiayi University, and was maintained for one week for long-term testing. Rectangular fish bowls were used. The size is $60 \times 45 \times 45 \mathrm{~cm}$ with $67.5 \mathrm{~L}$ water.

\section{Methods}

Moisture content

Each wood preservative-treated wood was measured by the CNS 452 (1995) Method Test for Moisture Content of Wood.

Density

Each wood preservative-treated wood was measured by the CNS 451 (1995) Method Test for Density of Wood.

Surface texture

Using a surface-texture measuring instrument (Semitsu, Tokyo), the surface texture of each wood preservative-treated wood was measured. This measurement was the degree of texture of fiber directions at the surface of the specimen. The average degree of the surface texture on the centerline of the specimen $(\mathrm{Ra})$, the degree of the texture at the highest point on the surface of the specimen (Rmax), and the average degree of the texture for 10 points on the surface of the specimen (Rz) were measured.

Color value

The wood preservative-treated wood was measured using a colorimeter (Nippon Denshoku NR-3000) at 3 randomly selected spots. In the CIE $1976 \mathrm{~L}^{*} \mathrm{a}^{*} \mathrm{~b} *$ color system employed, color is considered to consist of three major dimensions: hue, chroma, and lightness. $\mathrm{L}^{*}$ is the lightness or brightness variable and is generally the most important aspect of wood color changes to a viewer's eye, while $\mathrm{a}^{*}$ and $\mathrm{b}^{*}$ represent the chromaticity (hue and chroma) coordinates.

Long-term testing for water quality and fish body with preservative-treated wood leaching

The fish bowl test periods were $0,4,8,16,24,32$, and 48 weeks, loaded with CCA- and ACQ-treated specimen, respectively (as the control group). The CCA- and ACQtreated specimens, bamboo charcoal and Bey-Charng charcoal were the test groups. The fish bowl holding only water was the blank group. Taiwan porgies were placed in the aforesaid fish bowls. There were 20 Taiwan porgies with lengths of about $5 \mathrm{~cm}$ in each bowl, and the daily feed quantity was $1 \%$ of fish body weight. The consumption of CCA- and ACQ-treated specimens for the test group was one piece per bowl, the consumption of bamboo charcoal and Bey-Charng charcoal was $1000 \mathrm{~g}$ for each bowl. The treated specimen, bamboo charcoal or Bey-Charng charcoal, Taiwan porgies, and water sample were taken out at preset times for testing and analysis. Measurement of preservative content in treated wood

The wood preservatives content in CCA- and ACQtreated specimens (before tested as 0 week) was measured according to CNS 14495 with Atomic Absorption Spectrometry (Varian Model Spectr AA 220). The test specimens were powdered and then dissolved in sulfuric acid. The contents $\left(\mathrm{kg} / \mathrm{m}^{3}\right)$ of $\mathrm{Cr}\left(\operatorname{as~} \mathrm{CrO}_{3}\right)$, As (as $\left.\mathrm{As}_{2} \mathrm{O}_{5}\right)$, and $\mathrm{Cu}$ (as $\mathrm{CuO}$ ) compounds were tested by Atomic Absorption spectrometry. For ACQ, only the content of $\mathrm{Cu}($ as $\mathrm{CuO}$ ) compound ( $\mathrm{CuO}$ ) was measured. The above test specimens were leached for 4, 8, 16, 24, 32, and 48 weeks. The contents were measured in the aforesaid description.

Characterization of Charcoal adsorption

The iodine value and the methylene blue (MB) adsorption represented the adsorption of charcoals (before tested as 0 week). The charcoals were leached for 4, 8, 16, 24, 32, and 48 weeks.

The adsorption was measured with the iodine value according to JIS K 1474 (1991). The charcoals particle size was 40 mesh to 60 mesh, and the equation for determining the iodine value was $I=(10-\mathrm{K} * f) * 12.69 * 5 / \mathrm{M}$; ( $I$ iodine value $(\mathrm{mg} / \mathrm{g}) ; \mathrm{K}$ volume of sodium thiosulfate solution used for titration $(\mathrm{mL}) ; f$ ratio of $0.1 \mathrm{~N}$ sodium thiosulfate solution to $0.1 \mathrm{~N}$ iodine solution; $\mathrm{M}$ absolute dry weight of the specimen).

To determine the MB adsorption value, each charcoal (1 mg) was added to a $25 \mathrm{~mL}$ aqueous solution containing $1 \mathrm{~g} / \mathrm{L}$ of $\mathrm{MB}$, and shaken at room temperature $\left(30^{\circ} \mathrm{C}\right)$. When the aqueous solution became colorless, MB 
was added into the flask repeatedly to assure the equilibrium adsorption of MB. After filtration, the concentration of residual $\mathrm{MB}$ was determined using a UV-vis Spectrophotometer (CECIL, CE3041) at a wavelength of $664 \mathrm{~nm}$. The MB adsorption value was measured referring to Huang (2009) and Weng (2010).

$\mathrm{Cr}, \mathrm{As}$, and Cu elements analysis of charcoals

The time varying $\mathrm{Cr}$, As, and $\mathrm{Cu}$ element contents (\%) were measured by Fluorescence X-ray Harmful Element Spectrometer (XGT-1000WR) according to WEEE/RoHS/ELV green environmental standards.

Water quality sampling and sample analysis

The water quality samples leached for $0,4,8,16,24$, 32 , and 48 weeks were sampled $500 \mathrm{~mL}$, respectively, and analyzed as follows;

Electrical conductivity (EC): each water sample was measured by a pen type EC meter (Suntex SC-120), repeated 3 times

$\mathrm{pH}$ value: measured by desktop $\mathrm{pH}$ meter (Cyber Scan pH510), the collected water samples were measured by electrodes of $\mathrm{pH}$ meter.

Total dissolved solids in water: a uniformly mixed water sample was placed in an evaporating dish of the given weight, evaporated in an oven at 103 to $105^{\circ} \mathrm{C}$ to a constant weight. The increased weight was the total solids weight. The uniformly mixed water sample was filtered by a glass fiber filter disc of the given weight. The filter disc was dried in an oven at 103 to $105^{\circ} \mathrm{C}$ to a constant weight. The increased weight was the suspended solid weight. The total solids weight minus the suspended solid weight, or the filtrate of a water sample filtered by a glass fiber filter disc, followed the total solids detection procedure, and the total dissolved solids weight was obtained.

Total organic carbon and total nitrogen in water: the water sample was injected into a reactor with continuous gas input by an auto-injector or manual injection, and embedded with UV light, a peroxy-pyrosulfate solution, and acid solution, supplied at a rate. The organic carbon and inorganic carbon in the water sample were oxidized and converted into $\mathrm{CO}_{2}$, respectively, and led by the current carrying gas in the Undistributed Infrared Analyzer (Elementar; high TOC II), which can absorb $\mathrm{CO}_{2}$ specific wavelength. The concentrations of total organic carbon and total nitrogen were obtained, respectively, according to the total organic carbon analyzer setting conditions.

Measurement of $\mathrm{Cr}$, As, and $\mathrm{Cu}$ ions in water was measured by a Graphite Furnace Atomic Absorption spectrometry (FAAS). The equation for the concentration of heavy metals is $\mathrm{A}=\mathrm{A}^{\prime} \times \mathrm{F} \times(\mathrm{V} / \mathrm{W})$; $\mathrm{A}$ : concentration of heavy metals in sample $(\mathrm{mg} / \mathrm{kg})$; A': concentration of heavy metals in sample solution measured by calibration curve (mg/L); V: final constant volume (L) after sample pretreatment; W: original sample weight (kg, wet weight or dried weight); F: dilution rate.

Fish body testing

The Taiwan porgy was dissected. The dorsal flesh was pulverized, and about $0.50 \mathrm{~g}$ was placed in a microwave digestion bottle (weighing out $0.01 \mathrm{~g}$ ), mixed with 5 $\mathrm{mL}$ aqua fortis and $3 \mathrm{~mL} 35 \% \mathrm{H}_{2} \mathrm{O}_{2}$. The digestion bottle was locked and placed in the microwave digester for microwave digestion; system set output power of 50\%, heating time of $45 \mathrm{~min}$. The digestion bottle was cooled for future use, and the Atomic Absorption Spectrometer measured the $\mathrm{Cr}, \mathrm{As}$, and $\mathrm{Cu}$ in digest.

\section{RESULTS AND DISCUSSION}

\section{Basic properties of wood preservative-treated wood}

The basic properties of the two types (CCA and ACQ) of preservative-treated woods were investigated. The results are shown in Table 1 . The air-dried moisture content of CCA- and ACQ-treated woods was 11.39 and $12.27 \%$. The density of air- and oven-dried condition for CCA- and ACQ-treated woods was 0.35 and $0.50 \mathrm{~g} / \mathrm{cm}^{3}$. The total content of CCA in CCA- treated wood was $3.43 \mathrm{~kg} / \mathrm{m}^{3}$, including $\mathrm{CrO}_{3}\left(2.39 \mathrm{~kg} / \mathrm{m}^{3}\right), \mathrm{As}_{2} \mathrm{O}_{5}(0.75 \mathrm{~kg} /$ $\left.\mathrm{m}^{3}\right)$ and $\mathrm{CuO}\left(0.28 \mathrm{~kg} / \mathrm{m}^{3}\right)$; for ACQ-treated wood, it was $0.28 \mathrm{~kg} / \mathrm{m}^{3}$ only for $\mathrm{CuO}$. The Ra, Rmax and $\mathrm{Rz}$ of the degree of texture for ACQ and ACQ-treated woods on the fibers direction were 5.60-5.77, 22.84-29.69 and 46.4550.02 , respectively. Color changes are generally the most important aspect of wood-based materials to a consumer, particularly for furniture or floor use, and $\mathrm{L}^{*} \mathrm{a}^{*} \mathrm{~b}^{*}$ are also the most frequently measured parameters (Okano et al., 1995). Results of the colorimetric measurements of the two types of CCA and ACQ-treated woods, based on the CIE L* $\mathrm{a}^{*} \mathrm{~b}^{*}$ system, are also shown in Table 1. The results of the $\mathrm{L}^{*}, \mathrm{a}^{*}$ and $\mathrm{b}^{*}$ were $58.86,2.97$ and 20.86 for the CCA-treated wood, and 50.93, 5.47 and 19.08 for ACQ-one.

\section{Retention contents of preservatives in treated wood}

This study used an aquarium to simulate an aquatic environment. CCA- and ACQ-treated woods were added in as the heavy metal source in the water in order to evaluate the effect of the component loss on the water quality and fish body in long-term testing. The heavy metals in the water were adsorbed by charcoal, in order to know the effect of the heavy metals on water quality and fish body. The test results were analyzed according to wood preservative-treated woods, charcoals, water quality, and fish body.

Table 2 shows the retention contents $\left(\mathrm{kg} / \mathrm{m}^{3}\right)$ of $\mathrm{Cr}$ $\left(\mathrm{CrO}_{3}\right)$, As $\left(\mathrm{As}_{2} \mathrm{O}_{5}\right)$, and $\mathrm{Cu}(\mathrm{CuO})$ in the $\mathrm{CCA}$-treated woods and the copper compound $(\mathrm{CuO})$ in $\mathrm{ACQ}$-treated woods after different test periods. The retention contents of metal component decreased with time, they were $\mathrm{CrO}_{3}, \mathrm{As}_{2} \mathrm{O}_{5}$, and $\mathrm{CuO}$ are $1.81,0.65$, and $0.23 \mathrm{~kg} / \mathrm{m}^{3}$, respectively, after 4 weeks, and the leached rate is 24.42 , 14.06 , and $16.96 \%$, respectively. The retention contents of metal compounds are 1.40-1.15, 0.58-0.44, and 0.16$0.121 \mathrm{~kg} / \mathrm{m}^{3}$, respectively, during Week 24 to Week 48, and the leached rate range is 41.03-51.69, 22.98-41.86, and 44.26-57.49\%, respectively. According to Lin (1995), the leached rate of preservatives from treated wood is about $20 \%$ during the first 28 days of leaching tests, which is the most significant, the leached rate decreases 
Table 1. Basic properties of wood preservative-treated wood

\begin{tabular}{|c|c|c|c|}
\hline \multirow{2}{*}{ Test items } & & \multicolumn{2}{|c|}{ Type of specimen } \\
\hline & & CCA-treated wood & ACQ-treated wood \\
\hline Moisture content (\%) & & $12.27(0.37)$ & $11.39(1.76)$ \\
\hline Air-dried density $\left(\mathrm{g} / \mathrm{cm}^{3}\right)$ & & $0.39(0.05)$ & $0.50(0.07)$ \\
\hline Oven-dried density $\left(\mathrm{g} / \mathrm{cm}^{3}\right)$ & & $0.35(0.05)$ & $0.44(0.06)$ \\
\hline \multirow{4}{*}{$\begin{array}{l}\text { Content of preservative } \\
\left(\mathrm{kg} / \mathrm{m}^{3}\right)\end{array}$} & $\mathrm{TC}^{1)}$ & $3.43(0.37)$ & $0.28(0.04)$ \\
\hline & $\mathrm{CrO}_{3}$ & $2.39(0.40)$ & $-{ }^{2)}$ \\
\hline & $\mathrm{As}_{2} \mathrm{O}_{5}$ & $0.75(0.09)$ & - \\
\hline & $\mathrm{CuO}$ & $0.28(0.11)$ & $0.28(0.04)$ \\
\hline \multirow{3}{*}{$\begin{array}{l}\text { Texture degree to } \\
\text { horizontal fiber direction } \\
(\mu \mathrm{m})^{3)}\end{array}$} & $\mathrm{Ra}$ & $5.77(1.62)$ & $5.60(1.40)$ \\
\hline & $\mathrm{Rz}$ & $22.84(6.25)$ & $29.69(5.32)$ \\
\hline & $\operatorname{Rmax}$ & $46.45(7.25)$ & $50.02(9.84)$ \\
\hline \multirow{3}{*}{ Color value $^{4)}$} & $\mathrm{L}^{*}$ & $58.86(1.71)$ & $50.93(6.54)$ \\
\hline & $a^{*}$ & $2.97(0.92)$ & $5.47(1.50)$ \\
\hline & $\mathrm{b}^{*}$ & $20.86(1.06)$ & $19.08(1.49)$ \\
\hline
\end{tabular}

1) TC: Total content of preservatives: including contents of $\mathrm{CrO}_{3}, \mathrm{As}_{2} \mathrm{O}_{5}$ and $\mathrm{CuO}$

2) -: None

${ }^{3)}$ Ra: Average surface texture degree on centerline of specimen; Rmax: Texture degree of maximum high point on surface specimen; Rz: Texture degree for average ten points on surface specimen;

4) Color values: $\mathrm{L}^{*}$ : 0 to 50 dark direction, 51 to 100 light direction; $\mathrm{a}^{*}$ : 0 to +60 red direction, 0 to -60 green direction; $b^{*}: 0$ to +60 yellow direction, 0 to- 60 blue direction

Table 2. Retention content of $\mathrm{CrO}_{3}, \mathrm{As}_{2} \mathrm{O}_{5}$ and $\mathrm{CuO}$ in CCA- and ACQ-treated woods after testing the long-term test in water-based environment

\begin{tabular}{|c|c|c|c|c|}
\hline \multirow{2}{*}{ Week } & \multirow{2}{*}{ type of specimen } & \multicolumn{3}{|c|}{ Content $\left(\mathrm{kg} / \mathrm{cm}^{3}\right)$} \\
\hline & & $\mathrm{CrO}_{3}$ & $\mathrm{As}_{2} \mathrm{O}_{5}$ & $\mathrm{CuO}$ \\
\hline 0 & & $2.39(0.06)$ & $0.75(0.03)$ & $0.28(0.01)$ \\
\hline 4 & & $1.81(0.03)$ & $0.65(0.01)$ & $0.23(0.01)$ \\
\hline 8 & & $1.60(0.04)$ & $0.62(0.02)$ & $0.22(0.01)$ \\
\hline 16 & CCA-treated wood & $1.53(0.06)$ & $0.60(0.04)$ & $0.19(0.09)$ \\
\hline 24 & & $1.40(0.03)$ & $0.58(0.02)$ & $0.16(0.03)$ \\
\hline 32 & & $1.41(0.03)$ & $0.58(0.01)$ & $0.15(0.03)$ \\
\hline 48 & & $1.15(0.04)$ & $0.44(0.07)$ & $0.12(0.01)$ \\
\hline 0 & & - & - & $0.28(0.02)$ \\
\hline 4 & & - & - & $0.22(0.03)$ \\
\hline 8 & & - & - & $0.21(0.02)$ \\
\hline 16 & ACQ-treated wood & - & - & $0.19(0.02)$ \\
\hline 24 & & - & - & $0.17(0.01)$ \\
\hline 32 & & - & - & $0.17(0.01)$ \\
\hline 48 & & - & - & $0.13(0.03)$ \\
\hline
\end{tabular}

$$
- \text { : None }
$$

gradually, and is equivalent to this test result. The result also shows the CCA preservatives has been prohibited in many countries, is prohibited in Taiwan in $1^{\text {st }}$ January, 2016, and will gradually be replaced by less toxic ACQ preservatives or something else; however, the retention contents of preservatives in CCA-treated wood is still better than ACQ-one. In addition, the most compound leached from the CCA-treated wood was $\mathrm{CuO}$, followed by $\mathrm{CrO}_{3}$, and the least content is $\mathrm{As}_{2} \mathrm{O}_{5}$; the major compound leached from $\mathrm{ACQ}$-treated wood was $\mathrm{CuO}$, and the retention contents decreased from 0.28 to $0.13 \mathrm{~kg} / \mathrm{m}^{3}$ from the beginning (Week 0) to test end (Week 48). 


\section{Adsorption of charcoals for treated wood leached components}

Charcoals prepared of different materials have different physical and chemical characterizations, and the adsorption of charcoal can be obtained by measuring the iodine value and MB adsorption value. This study evaluates the characterizations of charcoal in water to determine the differences. The iodine value is the index of charcoal with micropore structure. The molecular diameter of iodine is $0.56 \mathrm{~nm}$, and the adsorbance of iodine can be the capability of adsorbing nonpolar micromolecules. Figure 1 (upper figure) shows the iodine value resulted of two charcoals before and after testing. The wood preservatives leached components in water were adsorbed when the charcoal was placed in the treated wood for the long-term test environment. The iodine value of charcoal in the ACQ-treated wood decreased more than that in CCA-one. Therefore, charcoal has better adsorption in water for components leached from ACQ-treated wood. Tsai (2006) indicated that bamboo charcoal has better adsorption for specific metals, such as $\mathrm{Pb}, \mathrm{Cu}, \mathrm{Cr}, \mathrm{Ni}$, and As; after 24-hour adsorption, the maximum adsorbance is 2.9 ppm for $\mathrm{Pb}$, followed by $\mathrm{Cu}$, $\mathrm{Cr}, \mathrm{Ni}$, and $\mathrm{Cd}$, and the minimum adsorptive value is $0.05 \mathrm{ppm}$ for As. Therefore, ACQ-treated wood leaches out more $\mathrm{CuO}$ compound, the charcoal adsorbs $\mathrm{Cu}$ better, the iodine value changes largely, and the adsorption of bamboo charcoal for treated wood leached components is estimated better than Bey-Charng charcoal.

The molecular diameter of methylene blue is about $1.3 \mathrm{~nm}$, and its adsorption can be the index for judging the capability of charcoal to adsorb large molecules.

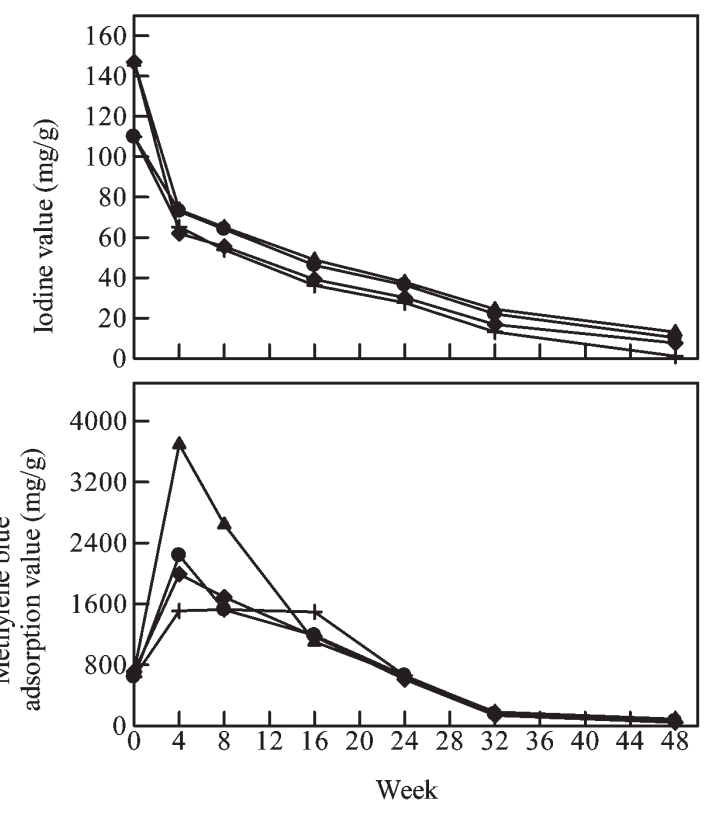

Fig. 1. Iodine value and methylene blue adsorption value of charcoals in CCA- and ACQ-treated woods after testing the long-term test in water-based environment.

Legends - : CCA-treated wood with bamboo charcoal;

- : CCA-treated wood with Bey-Charng charcoal : ACQ-treated wood with bamboo charcoal; ACQ-treated wood with Bey-Charng charcoal
According to the $\mathrm{MB}$ adsorption value in the lower figure of Figure 1, the MB decolorizing ability of charcoal was supposed to degrade while adsorbing the substances in water after long-term testing; however, the MB adsorption value increased in the first 4 weeks of testing. Shiah et al. (2003) indicated in the detection and analysis of bamboo charcoal characterization that different ions flow out of charcoal soaked in water for improving water quality, while the ions do not always exist in mesopores and micropores, it is apparent that the bamboo charcoal loses various components. However, the MB adsorption value decreased gradually as the test period extends beyond 4 weeks; when the test ends in week 48, the MB adsorption value of bamboo charcoal and Bey-Charng charcoal was $45.20 \mathrm{mg} / \mathrm{g}$ and $44.15 \mathrm{mg} / \mathrm{g}$, respectively, which was apparently lower than the 712.12 and $642.36 \mathrm{mg} / \mathrm{g}$ of that without bamboo charcoal or Bey-Charng charcoal. Therefore, charcoal loses substances as it is soaked in water at the initial stage of testing, the pores are released, and the substances in water are adsorbed.

\section{Effect of water quality on treated wood leaching with charcoal}

The $\mathrm{pH}$ value of water is determined by the hydrogen ion concentration in water. When the $\mathrm{pH}$ of water is too low, the toxic metal elements in nearby soil and rocks may dissolve, thus, killing aquatic animals, such as fish (Shi, 2003; Lee et al., 2004). When crops are irrigated with the water, the accumulated toxic metals will enter the human body via the food chain, and harm human health. Therefore, the $\mathrm{pH}$ value of water is very important for the environment (Lee et al., 2004).

According to Figure 2 (upper left figure), the water quality was near-neutral 7.16 before testing, after longterm testing, the $\mathrm{pH}$ value of the water with charcoal was higher than 7 , the $\mathrm{pH}$ value of the control group without charcoal decreased most apparently, the $\mathrm{pH}$ decreased with time, which may due to the excreta of Taiwan porgy in water containing $\mathrm{N}$ and $\mathrm{NH}_{3}$, and the $\mathrm{pH}$ of water decreased obviously. The $\mathrm{pH}$ values of the water samples with charcoal were mostly 7.0 to 8.5 , which might due to the charcoal containing abundant natural mineral substances of $\mathrm{Ca}, \mathrm{Mg}, \mathrm{Fe}, \mathrm{K}, \mathrm{Mn}$, and $\mathrm{P}$ metal ions in longterm testing, which are dissolved in water, thus, increasing the $\mathrm{pH}$ value of water, and the water becomes alkalescent water similar to natural mineral substance (Shiah et al., 2003). This phenomenon shows that charcoals can improve the $\mathrm{pH}$ of aquatic environment, and it has a certain effect on improving water acidification.

The electrical conductivity represents the ability of water to conduct current, and is related to the total ionic concentration in water, mobility, valence number, relative concentration, and water temperature. The concentration of electrolyte in water directly influences electrical conductivity, as its magnitude can indirectly represent the amount of electrolyte and salts in water (Shi, 2003). The initial electrical conductivity of tap water is about $305 \mu \mathrm{mho} / \mathrm{cm}$, and after long-term testing, as shown in Figure 2 (upper right figure), the electrical conductivity increased gradually with the test period, mean- 

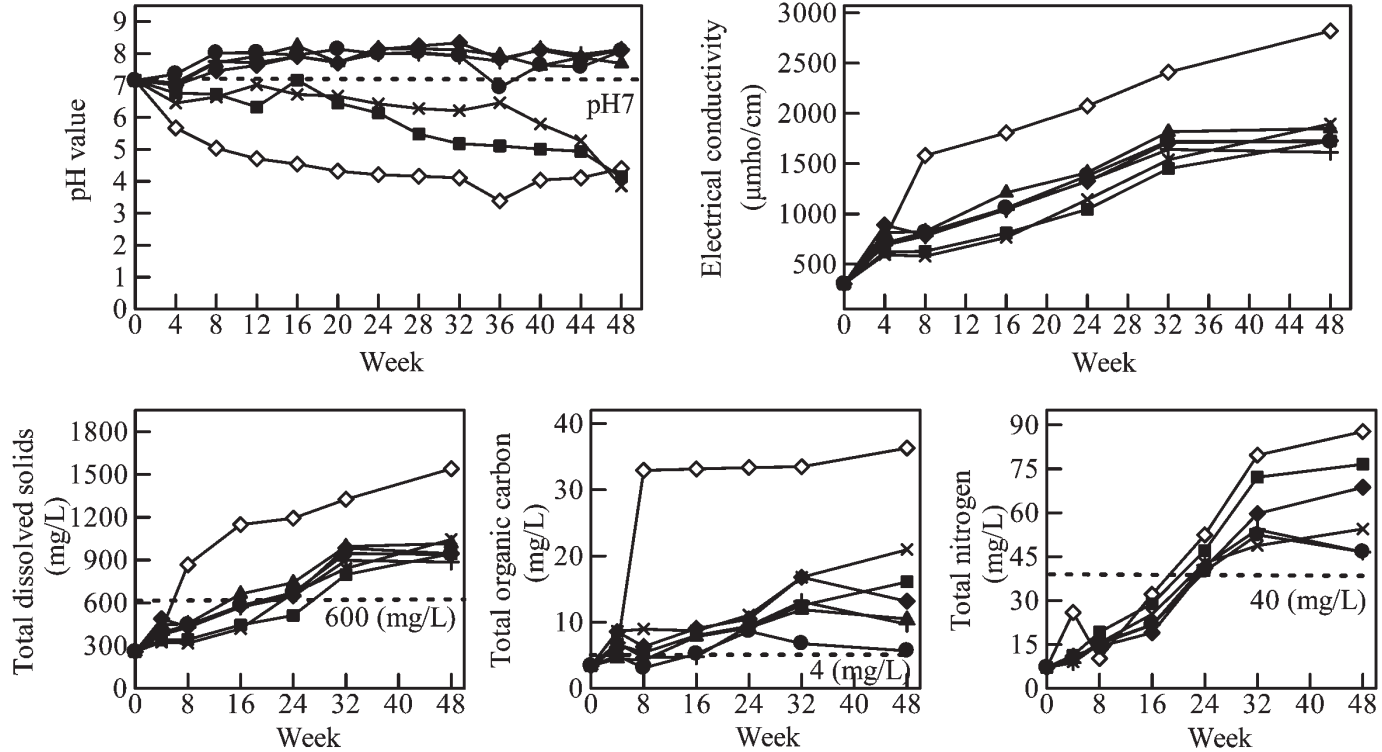

Fig. 2. pH value, electrical conductivety, total dissolved solids, tolal orgainc carbon and total nitrogen of water in CCA-and ACQ-treated woods after testing the long-term test in water-based environment.

Legends $\neg$ : Control; $\_$: CCA-treated wood; $\_$: CCA-treated wood with bamboo charcoal;

- : CCA-treated wood with Bey-Charng charcoal; $\rightarrow$ - : ACQ-treated wood;

: ACQ-treated wood with Bey-Charng charcoal; — — : ACQ-treated wood with Bey-Charng charcoal

ing the water contains more electrolyte because of the fish excreta and leached treated wood components. The electrical conductivity of the group with charcoal was higher than the others from the beginning, which might be due to some mineral substances released from the charcoal, thus, electrical conductivity was higher than that without charcoal. The electrical conductivity of the control group ( $2820 \mu \mathrm{mho} / \mathrm{cm}$ ) was higher than others, which might because the control group has no charcoal to adsorb the excreta of fish or the others.

According to the "water quality standard for drinking water", as declared by the Environmental Protection Administration (EPA), Executive Yuan, Taiwan in May 2003, the total dissolved solids must be lower than $600 \mathrm{mg} / \mathrm{L}$. Figure 2 (lower left figure) shows that, after long-term testing, the total dissolved content in water increased with time. The control group has exceeded the standard of EPA since the $6^{\text {th }}$ week; however, in terms of the total dissolved content in water of the test group, the group of CCA-treated wood with bamboo charcoal exceeds the standard in Week 16, while the remaining exceed the standard after 24 weeks, and the total dissolved solids in the water of the group with charcoal was higher than that without charcoal, which might because the fish excreta rendered the saturated adsorption of charcoal.

The EPA (2003) specified the threshold limit value of total organic carbon in drinking water sources of tap water as $4 \mathrm{mg} / \mathrm{L}$. According to Figure 2 (lower middle figure), the organic carbon content in the water before testing was $3.42 \mathrm{mg} / \mathrm{L}$, but exceeded the drinking water limitation since the $4^{\text {th }}$ week. The control group had the maximum $36.3 \mathrm{mg} / \mathrm{L}$ in 48 weeks, followed by the water with- out charcoal, then the waters with ACQ-treated wood and CCA-treated wood were 20.96 and $16.10 \mathrm{mg} / \mathrm{L}$, respectively. Therefore, charcoal could reduce the organic matter in water, and the time-varying organic carbon content of Bey-Charng charcoal was lower than that with bamboo charcoal, meaning the Bey-Charng charcoal had obvious effect on reducing the organic content in water.

The water pollution control articles of the Department of Health, Executive Yuan (2003) specifies the total nitrogen limitation in water as $40 \mathrm{mg} / \mathrm{L}$. According to Figure 2 (lower right figure), the total nitrogen contents of the control group and test group were within the limitation until Week 16, and while the control group had higher $32.14 \mathrm{mg} / \mathrm{L}$, it was still within the limitation. The total nitrogen of the test group with charcoal was lower than that without charcoal till the test ends in Week 48.

\section{Heavy metal ion analysis of charcoals, water quali- ty and fish body}

This test used the adsorption of charcoal to evaluate the effect of treated wood leached heavy metals on water quality and fish body. The microelement content (\%) was analyzed by Harmful Element Spectrometer with semi quantitatively displayed by Fluorescence X-ray, as shown in Figure 3 (upper left figure). According to the proportion of $\mathrm{Cr}$ in charcoal, bamboo charcoal had the best capability of adsorbing $\mathrm{Cr}$ in Week 4, which is $0.0154 \%$, and while it decreased with time, the BeyCharng charcoal retained about $0.011 \%$, meaning that bamboo charcoal had better adsorption effect on Cr ion, but was saturated after Week 4, while the adsorption of 
in Charcoals
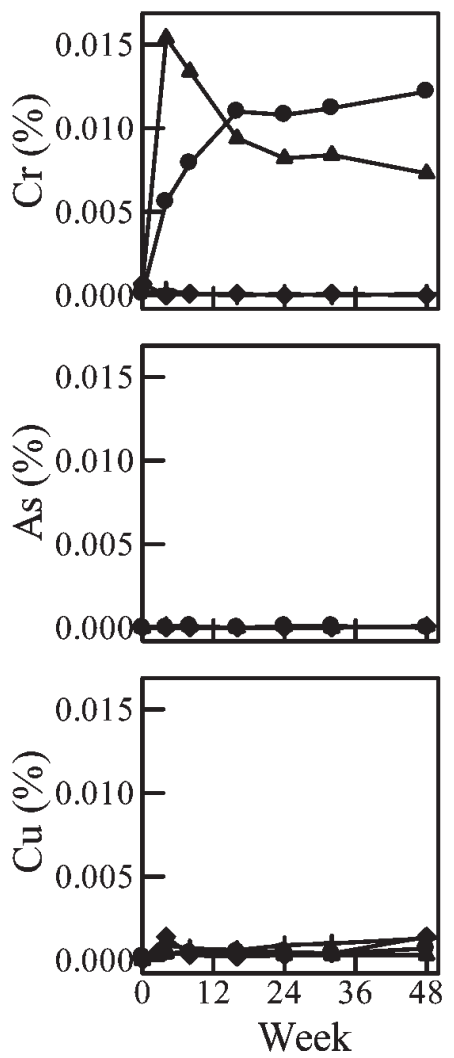

in Water
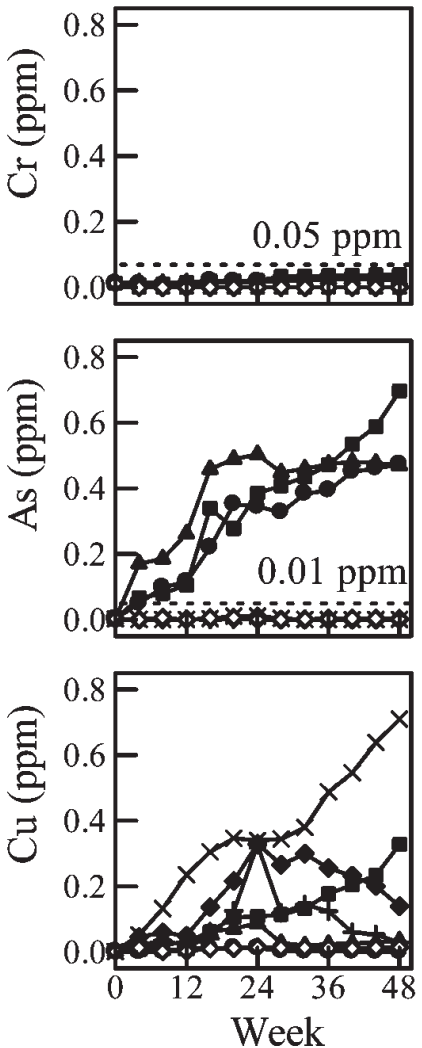

in Fish body
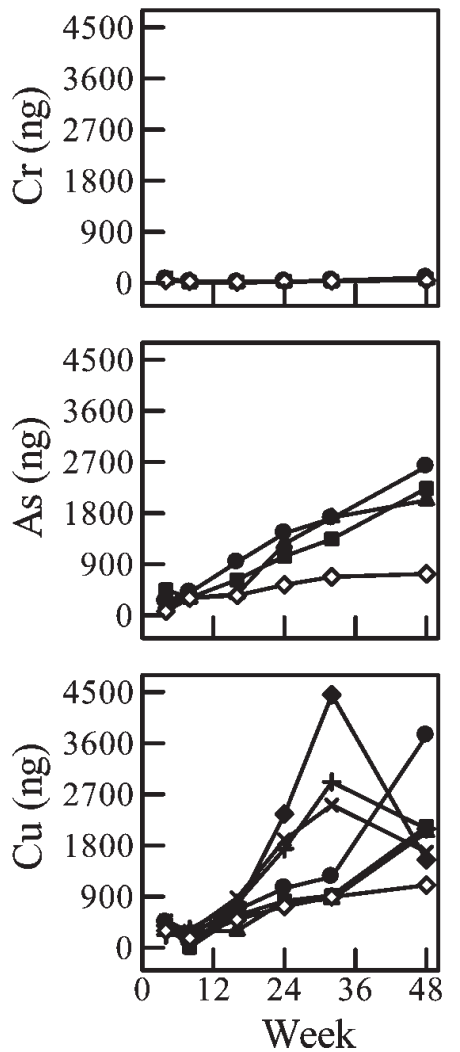

Fig. 3. Cr, As and $\mathrm{Cu}$ in charcoals, water and fish body after testing the long-term test in water-based environment. Legends $\neg$ : Control; $\_$: CCA-treated wood; $\_$: : CCA-treated wood with bamboo charcoal;

: CCA-treated wood with Bey-Charng charcoal; $¥$ — : ACQ-treated wood;

: ACQ-treated wood with bamboo charcoal; —1 : ACQ-treated wood with Bey-Charng charcoal

Bey-Charng charcoal lasted to Week 48. According to the middle left figure in the Fig. 3, bamboo charcoal or BeyCharng charcoal had little adsorption for the As ion. After long-term testing for charcoal, the $\mathrm{Cu}$ ion content was less than Cr, but there was little effect only (lower left figure). Therefore, it is indicated while charcoal has adsorption effect on $\mathrm{Cr}$ and $\mathrm{Cu}$ ions, the effect on As is not obvious.

Cr exists in the metallic state, as well as in the ionic condition; $\mathrm{Cr}^{3^{+}}$and $\mathrm{Cr}^{6^{+}}$are toxic, and $\mathrm{Cr}^{6^{+}}$has the maximum toxicity, meaning it has strong oxidizer, is water soluble, and penetrates tissue, thus, it can easily penetrate skin, causing serious harm to the human body. $\mathrm{As} \mathrm{Cr}^{3+}$ has lower penetration and absorption, it is less toxic (EPA, 2004; Sanders and.Windom, 1980; Sanders and Riedel 1987; Weis J. S. and P. Weis, 1992a, 1992b, 1995, 1996; Weis P. and J. S. Weis, 1999). According to Figure 3 (upper middle figure), after long-term testing, the group without charcoal only had the $\mathrm{Cr}$ ion content from CCA-treated wood, which was increased continuously, while the Cr contents in various water samples were within the safety standard of the EPA, and did not exceed the EPA standard (0.05 ppm). In water with charcoal (Figure 3 upper left figure), the adsorption of $\mathrm{Cr}$ ion is obvious in Week 4, which might because the adsorption of charcoal has been saturated; however, as the Cr con- tent was lower for the specimen without charcoal, the charcoal might have considerable adsorption effect on treated wood at the initial stage of leaching. According to Figure 3 (middle figure), the As content in nearly all CCA-treated wood was higher than the standard value (0.01 ppm), and there was no adsorption even if charcoal was applied (Figure 3 middle left figure). Figure 3 (lower middle figure) indicted that the leached component of $\mathrm{Cu}$ ion in water with CCA- and ACQ-treated woods since Week 4, and that of CCA-treated wood was markedly increased. While ACQ-treated wood leaches out more $\mathrm{Cu}$ ions, the adsorption decreased gradually after Week 16. This inferred that while charcoal has good adsorption for $\mathrm{Cu}$ ion, it is saturated gradually after 16 weeks, and the adsorption decreases gradually.

According to Figure 3 (upper right figure), while there was no difference in the Cr content in fish body, it might be correlated with the growth of the fish body. According to Figure 3 (middle right figure), the As content in the fish body did not exceed the standard; however, it accumulated with time, and the results of the retention contents in treated wood (Table 2) and water quality (Figure 3 middle figure) showed that the As content increased continuously, while the adsorption of charcoal decreased. Thus, the leaching of As ion from the CCA-treated wood containing As is need to be paid spe- 


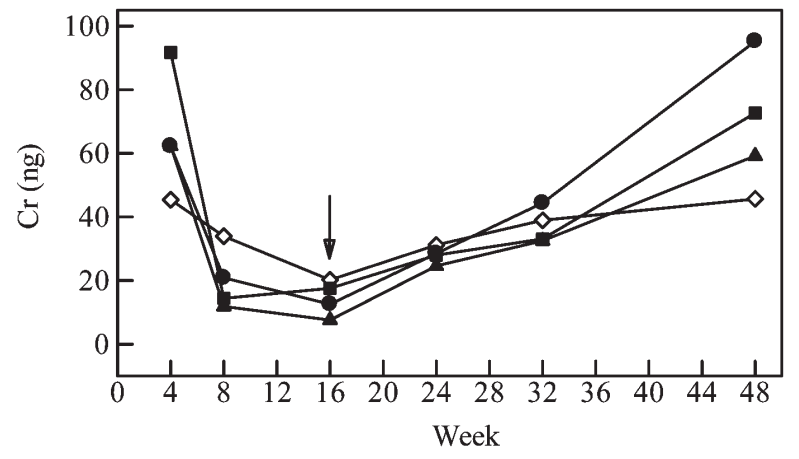

Fig. 4. Cr of fish body in CCA-treated wood after testing the longterm test in water-based environment.

Legends $\prec$ : Control;

- : CCA-treated wood;

- : CCA-treated wood with bamboo charcoal;

- : CCA-treated wood with Bey-Charng charcoal

cial attention to. In addition, the As ions of the test group with bamboo charcoal accumulated slowly before Week 16 , while that of various test groups increased gradually after 16 weeks. According to Figure 3 (lower right figure), the $\mathrm{Cu}$ content in fish body was always below the standard, and only the ACQ-treated wood increased in the late stage, but it was far from the standard value. Tsai (2006) indicated that the $\mathrm{Pb}$ adsorbance of charcoal can be $2.9 \mathrm{ppm}$, and the absorption of $\mathrm{Cu}$ ion is about $1.7 \mathrm{ppm}$. Therefore, charcoal has good capability of adsorbing $\mathrm{Cu}$, thus, the $\mathrm{Cu}$ ion leached from treated wood has less effect on the fish body than Cr and As ones.

Figure 4 is an enlarged view of $\mathrm{Y}$-axis (Cr content in fish body) of Figure 3 (upper right figure). It is observed that, after long-term testing, the Cr content in the fish body decreased gradually within the test period, which might be because the fish body was small at the initial stage; the Cr ion content was relatively high, and the $\mathrm{Cr}$ ion content in the fish body was apparently higher in Week 4, but the content decreased within the test period in Week 16. Weis et al. (1995) indicated that the organisms and larvae in the aquatic environment can absorb the metal ions in the water, and turn the invivo metal ions into appearance when growing their hard appearance (e.g. fish scale, hard shell of oyster). The Cr ion content in the fish body increased gradually after 16 weeks, which was the same as the $\mathrm{Cr}$ ion content in water (Figure 3 upper middle figure). Therefore, the limit of adsorption of charcoal is reached after 16 weeks, and then the $\mathrm{Cr}$ ion content in water and fish body increases accordingly.

\section{CONCLUSIONS}

To evaluate the effect of charcoal absorption on water quality and fish body in long-term testing, this study used the components leached from treated wood as the heavy metal source in water. After a 48-week long-term test, the retention contents of $\mathrm{CrO}_{3}, \mathrm{As}_{2} \mathrm{O}_{5}$ and $\mathrm{CuO}$ in the CCA-treated wood were $1.81,0.65$, and $0.23 \mathrm{~kg} / \mathrm{m}^{3}$, respectively; the ACQ-treated wood was $0.13 \mathrm{~kg} / \mathrm{m}^{3}$ at the end of the test, and the iodine value of bamboo char- coal and Bey-Charng charcoal decreased from 146.99 and $109.85 \mathrm{mg} / \mathrm{g}$, respectively, to $7.70-13.10 \mathrm{mg} / \mathrm{g}$; the MB adsorption value decreased from 712.12 and $642.36 \mathrm{mg} / \mathrm{g}$ to $44.15-89.02 \mathrm{mg} / \mathrm{g}$, meaning the charcoal actually has adsorption for water. The electrical conductivity and total dissolved solids of the water with charcoal were increased, and the $\mathrm{pH}$ value was kept above 7 . The content of heavy metals, organic carbon, and total nitrogen content in water with charcoal were lower than that without charcoal. In the scope of this study, the adsorption of charcoal for CCA-treated wood leached Cr ion content can last about 16 weeks, and there is good adsorption effect on $\mathrm{Cu}$ ion.

\section{ACKNOWLEDGEMENTS}

The authors are grateful to the Kunnyih Co. Ltd., Taiwan, for providing the experimental materials, to Professor T. S. Chin of Dept. of Aquatic Bioscience, National Chiayi University for teaching the Graphite Furnace Atomic Absorption spectrometry, and to Associated Professor S. R. Kuo of Dept. of Aquatic Bioscience, National Chiayi University for offering the experimental fish. We offer our sincere appreciation to the National Science Council and the Kunnyih Co. Ltd., Taiwan through Grant No. NSC 96-2622-B-415-001-CC3 for financial support.

\section{REFERENCES}

Brown, C. J. and R. A. Eaton 2001 Toxicity of chromated copper Arsenate (CCA)-treated wood to non-target marine fouling communities in Langstone Harbour. Portsmouth, UK. Marine Pollution Bulletin, 42(4): 310-318

Caquet, TH., L. Lagadic, O. Jonot, W. Baturo, M. Kilanda and P. Simon 1996 Outdoor experimental ponds (Mesocosms) designed for long-term ecotoxicological studies in aquatic environment. Ecotoxicology and Environment, 34: 125-133

China National Standard CNS 3000010181970 Preservative Treatment of Wood by Pressure Processes. Bureau of Standards, Metrology and Inspection (BSMI), Ministry of Economic Affairs, Taiwan ROC

China National Standard CNS $1449501048 \quad 2000 \quad$ Wood Preservatives. Bureau of Standards, Metrology and Inspection (BSMI), Ministry of Economic Affairs

Environmental Protection Administration 2001 Toxic Substances. Environmental Protection Administration (EPA), Executive Yuan, Taiwan ROC

Environmental Protection Administration 2003 Water Quality Standard for Drinking Water. Environmental Protection Administration (EPA), Executive Yuan, Taiwan ROC

Ministry of Health and Welfare 2003 Water Pollution Control. Ministry of Health and Welfare (MOHW), Executive Yuan, Taiwan ROC

Findlay, W. P. K. D. Sc. 1985 Preservation of Timber in the Tropic. Published in Nijhoff and Dr. W. Junk, Dordrecht, Boston USA.

Hunt, G. M. and G. A.Garratt 1975 Wood Preservation, Published in McGraw-Hill Book Company. USA

Hung, C. P. 2004 Wood and bamboo charcoal for life application. Forest Tech. Report, 11(3): 18-21

Huang, W. J. 2009 Investigation of Absorption Properties of Activated Carbon Fibers Prepared from Wood Pulp. Graduate Institute of Forest Products Science, College of Agriculture, Natioonal Chiayi University, Master thesis

Japanese Industrial Standards (JIS) K 14742007 Testing Method 
for Granular Activated Carbon. Japanese Standard Association, Tokyo, Japan

Lee, C. K., T. H. Shih and W. H Shioh (BY Clair N. Sawyer, Perry L. McCarty, Gene F. Parkin) 2004 Water Analysis. Tsang Hai Publishing. pp. 149-155

Lin, H. C., T. Ohuchi, Y. Murase, T. C. Shiah, L. T. Gu, M. J. Lee and Y. D. Wu 2006 Application of TGA and EDX Analysis to Evaluate the Process of Preservative-Treated Woods. Journal of the Faculty of Agriculture Kyushu University. Japan. 51(2): $337-344$

Lin, Y. Z., G. S. Hwang and I. S. Wang 2003 Introduction to production and utilization of bamboo charcoal. Forest Tech. Report, 10(3): 31

Lin, Y. L. 1995 Impregnation and leachability of Chromated Copper Arsenate preservatives. Forest Productions Industries. Taiwan, 14(2): 58-70

Okano, K., M. Suzuki, M. Habaishi, K. TathuMoto, N. Funata, T. Takahashi, K Tanika, I. Mitotuku and Y. Akiyama 1995 Wood-based Living Environment. Asakura Publishing Co. Ltd, pp. 350-412

Sanders, J. G. and H. L. Windom 1980 The uptake and reduction of arsenic species by marine algae. Environment, 10: 555-567

Sanders, J. G. and G. F. Riedel 1987 Control of trace element toxicity by phytoplankton. Recent Adv Phytochem, 21: 131-149

Shiah, T. C., G. S. Hwang, Y. S. Wong and H. P. Liou 2003 Analysis and inspection of bamboo charcoal properties. Forest Tech. Report, 10(3): 38-45

Shi, F. C. 2003 Analysis and Inspection of Water. New Wun
Ching Developmental Publishing Co., pp. 365-392

Tsai, M. H. 2006 Effect of Manufacture Conditions on the Metal Ion Absorption Ability of Bamboo Charcoal. School of Forestry and Resources Conservation, College of BioResources and Agriculture, National Taiwan University, Master thesis

Weis, J. S. and P. Weis 1922a Transfer of contaminants from CCA-treated lumber to Aquatic Biota. J Exp Mar Biol Ecol, 161: 189-99

Weis, J. S. and P. Weis 1922b Construction materials in estuaries reduction in the epibiotic community on Chromated Copper Arsenate (CCA)-treated wood. Mar Ecol Prog Series, 83 $45-53$

Weis, P. S., Weis, J. Couch, C. Daniels and T. Chen 1995 Pathological and genotoxicological observations in oyster (Crassostrea virginica) living on Chromated Copper Arsenate (CCA)-Treated Wood. Mar Environment Res, 39: 275-278

Weis, J. S. and P. Weis 1996 Reduction on Toxicity of Chromated Copper Arsenate (CCA)-treated wood as assessed by community study. Mar Environment Res, 41: 15-25

Weis, J. S. and P. Weis 1999 Accumulation of metals in consumers associated with Chromated Copper Arsenate-treated wood panels. Mar Environment Res, 48: 73

Weng, Y. C. 2010 Evaluation of Adsorption Properties and Mutagenicity of Activated Carbons Refined from Charcoals. Graduate Institute of Forest Products Science and Furniture Engineering, College of Agriculture, Natioonal Chiayi University, Master thesis 